\title{
Manual acupuncture associated with amitriptyline for treatment of tactile allodynia at concha of the ear: case report and 12-month follow up*
}

\author{
Acupuntura manual associada à amitriptilina para o tratamento da alodínia tátil em região de \\ concha do pavilhão auricular. Relato de caso e acompanhamento de 12 meses
}

Alex Barbosa Nunes', Marise Sano Suga Matumoto', Edson Shizuo Tanaka', Wagner de Oliveira ${ }^{1,2}$
${ }^{*}$ Received from University of São Paulo, Clinicas Hospital, School of Medicine, São Paulo, SP, Brazil.

DOI 10.5935/1806-0013.20140050

\section{ABSTRACT}

BACKGROUND AND OBJECTIVES: Allodynia is a pain induced by stimuli which normally do not induce pain; it is caused by changes in sensory specificity. Acupuncture may be used for neuropathic pains such as allodynia or hyperalgesia. However, most studies in this area are in animal models. This study aimed at reporting the first case of efficacy of the association of acupuncture and amitriptyline in human being with tactile ear allodynia.

CASE REPORT: Female patient, 46 years old, complaining of paroxysmal pain, in shock, triggered by touch on the right concha of the ear, irradiating to ipsilateral fundus, as a consequence of epidermoid carcinoma excision in cranial posterior fossa six years ago. Other sequelae of such surgery were right central facial paralysis and left hemiparesis; however they were not her current complaint. Previously, paroxysmal pain had been only partially controlled with amitriptyline, being patient then referred for tentative treatment with acupuncture. Two acupuncture points were selected by the manual technique, together with the maintenance of previous amitriptyline. There has been pain decrease, being that at fifth consultation patient has withdrawn the use of amitriptyline on her own. Pain had totally regressed after the seventh consultation.

CONCLUSION: Acupuncture was effective to treat allodynia, with no symptoms recurrence even after six months without intervention or drug use. For being the first report of this association in human beings, specifically for allodynia, further studies are needed.

Keywords: Acupuncture, Amitriptyline, Earache, Therapy with acupuncture, Touch.

1. University of São Paulo, Clinicas Hospital, School of Medicine, São Paulo, SP, Brazil.

2. State Paulista University "Júlio de Mesquita Filho", São José dos Campos, SP, Brazil.

Submitted in June 24, 2014

Accepted for publication in August 25, 2014

Conflict of interests: none. Sponsoring sources: none.

Correspondence to:

A/C Prof. Dr. Wu Tu Hsing or Prof. Dr. Wagner de Oliveira

Centro de Acupuntura IOT HC FMSUP.

Rua Ovídio Pires de Campos, 333 - 3º andar, sala B-311.

05403-010, São Paulo, SP. Brasil.

E-mail:bn.alex@gmail.com

(C) Sociedade Brasileira para o Estudo da Dor

\section{RESUMO}

JUSTIFICATIVA E OBJETIVOS: Alodínia é uma dor provocada por estímulos que normalmente náo gerariam dor; causada por alteraçóes da especificidade sensorial. A acupuntura pode ser usada para dores neuropáticas como a alodínia ou hiperalgesia. Entretanto, a maioria dos estudos na área são em modelos animais. O objetivo deste estudo foi relatar o primeiro caso de eficácia da associação entre acupuntura e amitriptilina em um ser humano com alodínia tátil auricular.

RELATO DO CASO: Paciente do gênero feminino, 46 anos, queixando de dor paroxística, em choque, desencadeada por toque na regiáo de concha do pavilháo auricular direito, irradiando-se para fundo de olho ipsilateral, decorrente da excisão de carcinoma epidermoide em fossa posterior do crânio havia seis anos. Outras sequelas daquela cirurgia foram a paralisia facial direita de origem central e hemiparesia esquerda; entretanto, náo constituíam a queixa atual. Previamente, a dor paroxística havia sido controlada apenas parcialmente com amitriptilina, sendo a paciente então encaminhada para tentativa de tratamento com acupuntura. Foram selecionados dois pontos de acupuntura pela técnica manual concomitantemente à manutençáo da amitriptilina prévia. Verificou-se diminuição da sintomatologia álgica, sendo que na quinta consulta a paciente suspendeu o uso da amitriptilina por conta própria. Após a sétima consulta foi observada a completa regressão da dor.

CONCLUSÃO: A acupuntura mostrou-se eficaz no tratamento da alodínia, náo havendo retorno da sintomatologia mesmo após seis meses sem intervenção ou uso do fármaco. Por ser o primeiro relato dessa associação em ser humano, especificamente para a alodínia, mas mais estudos são necessários.

Descritores: Acupuntura, Amitriptilina, Dor de orelha, Tato, Terapia por acupuntura.

\section{INTRODUCTION}

Peripheral innervation injuries may result in chronic neuropathic pain characterized by spontaneous sensation of burning, hyperalgesia or allodynia. Allodynia is a neuropathic symptom, defined as pain induced by stimuli which normally would not induce pain, and may also be generated by sensory specificity changes.

It has been shown that neuropathic pain does not respond to 
conventional analgesics, so additional approaches, such as acupuncture, are often used ${ }^{1}$.

Acupuncture involves stimulation of specific body areas, called acupoints, by means of various techniques, including the insertion of fine needles through skin surface, followed by manual or electrical manipulation. Acupuncture has been used for a long time by the Traditional Chinese Medicine (TCM). Studies have shown that it is effective to relieve chronic pain ${ }^{1}$.

This study aimed at reporting the first case of efficacy of the association of acupuncture and amitriptyline in human being with tactile ear allodynia.

\section{CASE REPORT}

Female patient, 46 years old, referred by the physiatrist to the Ambulatory of Acupuncture in Orofacial Pain, School of

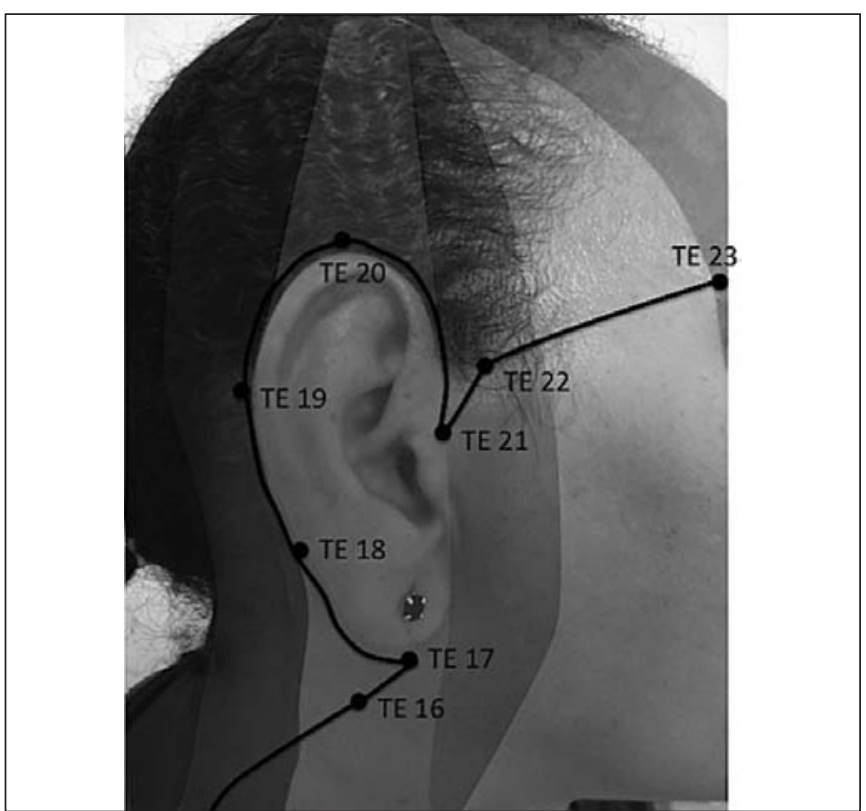

Figure 1. Triple energizer (TE) meridian and wrist ankle technique areas represented at the side of the face. Different wrist ankle technique areas are represented by vertical strips. TE meridian pathway is represented by the line. Points on the line represent different TE meridian acupoints
Medicine, University of São Paulo, to treat paroxysmal, shock pain, triggered by touching the concha of the right ear, irradiating to the ipsilateral fundus. Patient had also other symptoms, such as right face paralysis of central origin and left hemiparesia. All symptoms had started six years ago, caused by the excision of epidermoid tumor in posterior skull fossa. Before being referred to acupuncture, patient was pharmacologically treated with amitriptyline $(50 \mathrm{mg} /$ day $)$ in the first 12 months and then maintained with $25 \mathrm{mg} /$ day in subsequent 60 months, with adverse effect of sleepiness and poor pain modulation result. In the last 12 months patient reported worsening of pain.

We decided to maintain amitriptyline $(25 \mathrm{mg} /$ day $)$ simultaneously with acupuncture, having selected the Triple Energizer3 (TE3) acupoint, together with the Wrist Ankle Technique in wrist area 4 , both for encompassing the pain area (Figure 1) and for its indication according to TCM.

Patient's evolution was evaluated at every consultation by the pain verbal scale (PVS) pre and post acupuncture. Pain improvement can be seen in table 1 .

Already in the fourth consultation relief has allowed patient to touch the region again (Figure 2).

Table 1. Patient's pain graduation along treatment

\begin{tabular}{|c|c|c|}
\hline Consultation date & PVS pre & PVS post \\
\hline $11 / 22 / 12$ & 8 & 2 \\
\hline $11 / 29 / 12$ & 9 & 6 \\
\hline $03 / 07 / 13$ & 10 & 4 \\
\hline $03 / 14 / 13$ & 9 & 0 \\
\hline $03 / 21 / 13$ & 0 & 0 \\
\hline $04 / 04 / 13$ & 8 & 0 \\
\hline $04 / 11 / 13$ & 2 & 0 \\
\hline $04 / 18 / 13$ & 0 & 0 \\
\hline $04 / 25 / 13$ & 0 & 0 \\
\hline $05 / 02 / 13$ & 0 & 0 \\
\hline $08 / 29 / 13$ * & \multicolumn{2}{|c|}{0} \\
\hline $11 / 21 / 13^{* *}$ & \multicolumn{2}{|c|}{0} \\
\hline
\end{tabular}

PVS: pain verbal scale reported before and after acupuncture in respective consultations. ${ }^{*}$ Control 3 months after acupuncture. ${ }^{\star \star}$ Control 6 months after acupuncture.

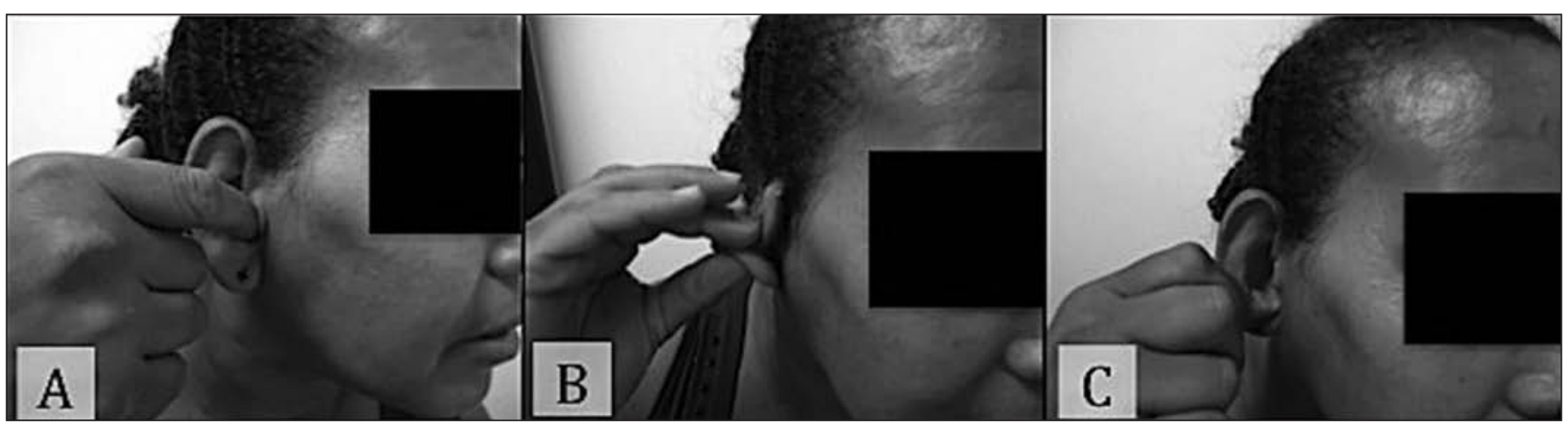

Figure 2. Sequence of movements previously precluded by allodynia In the fourth consultation patient could touch the ear again $(A)$, also bending $(B)$ and pulling $(C)$ it. 
At fifth consultation, patient, by herself, has definitively interrupted amitriptyline without pain relapse.

After the seventh consultation there has been total pain regression, which was maintained during the next six control months.

\section{DISCUSSION}

Neuropathic pain is a complex phenomenon involving pathophysiological mechanisms both in the central and peripheral nervous systems. The exact neuropathic pain mechanism and the inter-relationship among such mechanisms, signs and symptoms is not totally explained, as well as there is no consensual therapy, making it a difficult to treat chronic disease ${ }^{1}$.

Acupuncture analgesic mechanisms have been widely explored since the 1970s. Preliminary studies have proven that acupuncture promotes endogenous opioids release ( $\beta$-endorphin, encephalin, endorphin and dynorphin). In addition to endogenous opioids, serotonin is also pointed as one of acupuncture action mechanisms ${ }^{2}$. Descending serotoninergic inhibitory pathway is suggested as important acupuncture analgesic mechanism, collaborating with endogenous opioids.

TE3 acupoint is located in the dorsal surface of the hand, in a depression between the $4^{\text {th }}$ and $5^{\text {th }}$ metacarpi, close to metacarpophalangeal joint and some of its functions in TCM are: elimination of external pathogenic factors, such as wind and heat; meridian clearing; benefit ears; clear mind and vision; regulate and stimulate circulation Qi and circulate stagnated liver Qi.

The area 4 (Upper 4) of the wrist ankle technique is a strip going through the side of the trunk, in its Yang part, which encompasses head, ear, mastoid process, side of the neck, temporomandibular joint (TMJ) and lateral face of radius, in forearm dorsum, the needling point of it is in the large bowel meridian, two tsun (Chinese inches) above the wrist ${ }^{3}$. As to the use of area 4, old TCM texts already described the use of skin meridians ( $\mathrm{PiBu}$ ) to treat pain and other neurological problems. These meridians are superficially aligned and closely related to primary meridians. In addition, skin and central nervous system have the same embryo origin and for this reason skin meridians are commonly used to treat pain and other neurological diseases ${ }^{3}$.

In behavioral studies using different points also indicated for neuropathies, tactile allodynia was significantly improved by the Stomach 36 (ST36) acupoint, however not so effective with Spleen9 (SP9). Thermal allodynia to cold has been inhibited by SP9, but not by ST36. These results show that acupuncture efficacy for neuropathic pain depends on pain characteristics. Electrophysiological studies with neuropathic rats have shown that dorsal root $A \beta$ fibers response to mechanical stimulation (Von Frey Filament Test) and to cold stimulation (Acetone) were decreased by acupuncture both with ST36 and SP9. These results indicate that both types of allodynia may be inhibited by both acupuncture points. According to these results, acupuncture may be an effective treatment to relieve neuropathic pain ${ }^{1}$.

Manual acupuncture unilaterally applied, be it by isolated (SP6 or ST36) or associated points (SP6 + ST36), was as efficient as gabapentin $(30 \mathrm{mg} /$ day $)$ to decrease mechanical sensitivity when induced by spinal nerves ligation (SNL) in rats ${ }^{4}$. These effects were seen both in the acute phase (5 days after SNL) and in the subchronic phase (14 days after $\mathrm{SNL}$ ), being transient in both cases and reversible by naloxone without tolerance effects. The durability of this effect is increased by adding the number of needles (SP6 + ST36) ${ }^{4}$. Such fact may be explained by the concept of acupuncture "dose".

So, it is supposed that the association of TE3 acupoints with wrist area 4 would produce a summation effect (increased acupuncture "dose"), contributing for the maintenance of lack of tactile allodynia even during the follow-up period without intervention.

The association of manual acupuncture effects and amitriptyline may have also contributed for the end of pain and maintenance of the effect in the 6 follow-up months after the end of treatment. Antidepressants such as amitriptyline are used in neuropathies ${ }^{6}$ for potentiating the effect of endogenous opioid mechanisms and for increasing pain inhibitory pathways activity, especially serotoninergic and noradrenergic pathways ${ }^{6,7}$. Such mechanisms have possibly potentiated those produced by manual acupuncture: activation of descending inhibitory system ${ }^{8}$ and involvement of peptides and opioid receptors 9 . Summation effects of amitriptyline and low-level electroacupuncture have been already proven in animal models, including by converting animals non-responders to acupuncture into responders ${ }^{10}$.

So, initially the association of acupuncture and amitriptyline and then acupuncture alone (since the patient has withdrawn amitriptyline by herself), were effective to eliminate allodynia-induced pain during the 12 follow-up months. Therapy effect was considered gradual and cumulative. After six months without intervention, symptoms have not relapsed.

Acupuncture protocols applied to the patient are already consubstantiated and indicated by textbooks and scientific papers. However, both pain elimination in the 12 followup months (in general not reported in allodynia treatments with acupuncture) and patient's decision to withdraw amitriptyline without informing professionals assisting her, make this case report unique.

\section{CONCLUSION}

It is suggested that from now on studies conceived through methodologies with higher strength in the pyramid of scientific evidences are developed to unveil neurophysiologic mechanisms involved in tactile allodynia improvement via manual acupuncture alone or in association with amitriptyline. 


\section{REFERENCES}

1. Cha MH, Choi JS, Bai SJ, Shim I, Lee HJ, Choi SM, et al. Antiallodynic effects of acupuncture in neuropathic rats. Yonsei Med J. 2006;30;47(3):359-66.

2. Lin JG, Chen WL. Acupuncture analgesia: a review of its mechanisms of actions. Am J Chin Med. 2008;36(4):635-45.

3. Wen TS. Manual Terapêutico de Acupuntura. Barueri: Manole; 2008.

4. Cidral-Filho FJ, da Silva MD, Moré AO, Córdova MM, Werner MF, Santos AR. Manual acupuncture inhibits mechanical hypersensitivity induced by spinal nerve ligation in rats. Neuroscience. 2011;193:370-6.

5. White A, Cummings M, Barlas P, Cardini F, Filshie J, Foster NE, et al. Defining an adequate dose of acupuncture using a neurophysiological approach--a narrative review of the literature. Acupunct Med. 2008;26(2):111-20.

6. Sindrup SH, Jensen TS. Efficacy of pharmacological treatments of neuropathic pain: an update and effect related to mechanism of drug action. Pain. 1999;83(3):389-400.

7. Tura B, Tura SM. The analgesic effect of tricyclic antidepressants. Brain Res. 1990;518(1-2):19-22.

8. Takeshige C, Sato T, Mera T, Hisamitsu T, Fang J. Descending pain inhibitory system involved in acupuncture analgesia. Brain Res Bull. 1992;29(5):617-34.

9. Chen XH, Han JS. All three types of opioid receptors in the spinal cord are importan for 2/15 Hz electroacupuncture analgesia. Eur J Pharmacol. 1992;211(2):203-10.

10. Fais RS, Reis GM, Rossaneis AC, Silveira JW, Dias QM, Prado WA. Amitriptyline converts non-responders into responders to low-frequency electroacupuncture-induced analgesia in rats. Life Sci. 2012;91(1-2):14-9. 